\title{
9 \\ Sir Allen Brown: An Exemplary Public Servant
}

\author{
Sir Peter Lawler
}

\begin{abstract}
Allen Brown was described - I suspect by Fin Crisp - as Nugget Coombs' Vicar-General. This is an insightful and appropriate ecclesial analogy. Allen's appointment as Vicar-General marked the beginning of a 16-year career as one of the key players at the centre of Commonwealth Government administration. This was a watershed time of change in the reach of federal government and the nature of its administrative arrangements. When Coombs was commissioned to create the Department of Post-War Reconstruction, he already knew Allen Brown as a staff member and colleague in the wartime Rationing Commission. He had evidence of Allen's strength as an administrator - just the man to get the machinery of Coombs' ad hoc enterprise up and running for the effective discharge of the varied and nationwide activities assigned to it. Nugget also knew that his Vicar-General could and would as necessary fill the directorgeneral's shoes. He knew Allen was a top-class policy thinker with remarkable vision and a sure sense of the department's specific mission - someone who could help identify and set in motion major initiatives and projects in the service of that mission.
\end{abstract}

Brown did not meet all the canonical requirements for Vicar-General. He did not have the tonsure and he was not celibate - he had a wife, Hilda, and three children to whom he was devoted. But he was over 25 years of age (33 in fact) and was certainly commendable for the probity of his life, for his prudence, and for his knowledge of the law. He had an excellent academic pedigree: Caulfield Grammar, Wesley College, and Queen's College at the University of Melbourne, from where he gained a Master's degree in law. Better still, he had had the best part of a decade in the real world as a practising, successful and wellliked solicitor in country Victoria. In Post-War Reconstruction and the Prime Minister's Department, Allen Stanley Brown's staff knew him affectionately as ASB. Menzies came quite quickly to refer to him, also affectionately, as Bruno ('Where's Bruno?') or, less frequently, as 'le brun'. Menzies was fond of such tags: 'Black Jack' McEwen was 'le noir'. 
The Seven Dwarfs and the Age of the Mandarins

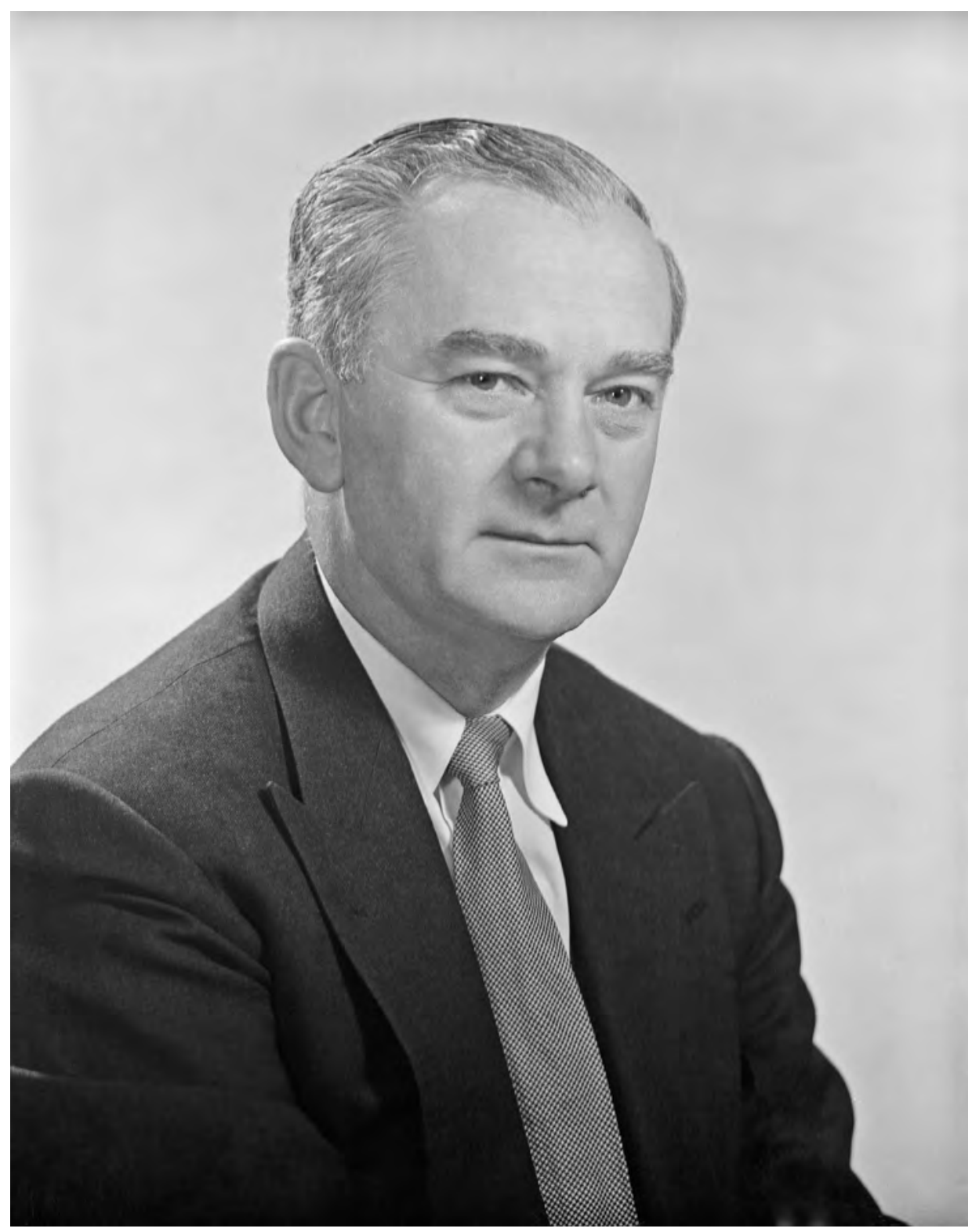

Sir Allen Brown, 1958

Source: National Archives of Australia, A1200, L27006 
There were two segments of ASB's 16-year career at the centre of Commonwealth administration and political affairs: first, from 1944, some five-and-a-half years as deputy director-general and a few final months as director-general of Post-War Reconstruction; and, second, his 10 crucial years from 1949 to 1959 as permanent head of the Prime Minister's Department. In each of these career segments ASB faced a similar administrative challenge - to create a Department of State. In the one case the department was a temporary creation set apart from regular Commonwealth departments. Few of the staff in Post-War Reconstruction had started their public service careers as telegraph messengers. It was an exciting, vibrant and constantly changing enterprise of young men (and some women), with a mission to promote ways and means for a better Australia. By early 1950, its work was over and it was abolished. In the second case, an existing central department was to be created anew to serve the prime minister and cabinet as one of the key departments at the top level of the departmental hierarchy. As it was, the Prime Minister's Department had been allowed to become something of a non-entity - a mere handful of staff tucked away in a few rooms in West Block. It needed to be thoroughly and permanently transformed. Brown was highly successful in each of these two career segments, but it is for his re-creation of the Prime Minister's Department that he best deserves to be remembered. In this he is a standout amongst the seven dwarfs - whichever seven is identified.

What sort of man was ASB? What was he like to know? Menzies is quoted as saying of Brown, 'He can see further through a brick wall than anyone else I know'. I would add that ASB could also see through people. He has been characterised as a naturally taciturn man with a laconic style of communication. I found him a cheerful, warm, caring, rather unassuming and humble person. He had a nice sense of humour. He was quick to see the droll side of things and would sometimes exploit it to defuse awkward situations. He had a protective amount of cynical streak. Here was a quiet man with great strength of character.

His personal secretary from the early days, Nalda Richards, remembers Brown as a man who never lost his temper and who, when he came as secretary to Prime Minister's in West Block in 1949, would take his turn in preparing morning and afternoon tea for the total staff - gathered in one room. I remember how, as deputy director-general in 1944, ASB batched with three decent but lower-level young public servants in a scruffy flat in Civic. This accommodation was above Charlie Thompson's Chemist Shop; it was known simply but ominously as The Flat. Some thought the deputy director-general should have booked into Beauchamp House or Acton Hotel but others saw the flat as a nice democratic touch. 
It was said of one of the dwarfs that he had a tongue barbed with fishhooks and no respect for anybody - an uncharitable caricature surely, but it could apply to more than one of them. But it certainly did not apply to Allen Brown. He was courteous and respectful - and at ease - whether with prime ministers and royals or with the lowliest clerk. I recall how ASB used to joke that when making his final notes after the Cabinet meeting, alone at his little side table in the Cabinet Room, with ministers tucking into food and pouring drinks in the Ante-Room, he would write down 'what he thinks they thought they ought to have said'.

At times ASB was known to indulge in doggerel or word play as, indeed, was Menzies. Researchers in the archives of the Prime Minister's Department will likely come across examples. When the Queen Mother came to Australia in 1958, ASB found favour with her and her entourage. Somehow the Queen Mother must have encountered some of ASB's doggerel and enjoyed it. Later, when calamity struck and the Queen Mother found herself marooned in Mauritius the cowling having fallen off the engine of the Qantas plane taking her home via South Africa - she called for the solace of some of Sir Allen's 'poetry'. And, solemnly, over the airwaves, went ASB doggerel of doubtful quality. It began: 'A cowling is a piece of tin, To keep an aircraft engine in'; it later featured something about 'When you're in Mauritius, And you're feeling rather vicious'. These anecdotes illustrate something of what ASB was like to know.

Allen Brown deserves great credit for his essential share in the successes of Post-War Reconstruction; not only the large administrative successes such as the Commonwealth Reconstruction Training Scheme, but project and policy successes as with The Australian National University; or in the department's economic section and its White Paper on Full Employment; or in the 'missionaries' that Post-War sent out into various parts of Commonwealth administration.

ASB was decisively involved in two notable projects. Sir William Hudson's name comes to mind when the Snowy Scheme is mentioned, and rightly so, but ASB in Post-War and later as secretary of Prime Minister's played a decisive part in making the scheme happen. He identified its huge possibilities and was an advocate from the very beginning. He then worked with Commissioner Tom Lang to lock in vital United States expertise, and, finally, he was a persuasive adviser with the 1950s Coalition Government to ensure that the Snowy Scheme continued to completion as planned.

The other project I want to underline is of more than passing interest but perhaps less well known. This is Post-War's studies and discussions about the administrative arrangements that ought to be developed to service government at the centre - that is the Prime Minister, the Cabinet and the committees of Cabinet. Chifley, prime minister and treasurer in 1945, felt both the administrative 
and the political need for an efficient Cabinet Office system and for quality alternative sources of advice in his own department. Allen Brown turned to the British Cabinet Office as a model and to the Cabinet secretary, Sir Norman Brook, for ideas and staff exchanges. So when Chifley appointed ASB in mid-1949 to be secretary of Prime Minister's Department, it was not exactly without preamble or out of a clear blue sky.

When the Coalition Government under Menzies came to power in December 1949, Allen Brown had been secretary of Prime Minister's for only six months. He had already begun to build up staff numbers by transfers from Post-War and especially from its Economic Section. The Coalition had believed, not without reason, that Post-War had harboured a nest of Labor Party supporters. Now they were similarly suspicious of Prime Minister's. This presented a problem with which ASB had to deal.

Brown might have had another problem - old Frank McKenna, the deputy secretary he inherited in Prime Minister's. McKenna had firmly believed that Chifley was going to appoint him as the secretary, so Brown might have had a disaffected deputy secretary on his hands. McKenna had lived through many trials in the Prime Minister's Department - a period of banishment to the Defence Department when the Prime Minister, William Morris Hughes, had purged Catholics from his department in 1917, and various heads of department of indifferent quality.

McKenna had begun his career as a telegraph messenger. He had no academic qualifications, yet he had progressed on-the-job to be an eminent public servant of the old school: dignified; of great courtesy; careful about due process and detail; deploying abundant common sense; shrewd and capable in the cut and thrust of debate; accurate and candid in his assessment of personalities. McKenna's disappointment, when told by Chifley that young Mr Brown from Post-War Reconstruction was to head up Prime Minister's Department, was something ASB could feel with him. ASB told me that Frank had every reason to expect to succeed Strahan and could have filled the position with credit.

The outcome speaks for the human quality of each of these two men. They developed the warmest regard for each other. McKenna saw that young Brown could make the department what it ought to be and what he, McKenna, wanted it to be. McKenna welcomed that and gave ASB whole-hearted support. Brown was always ready to recount with gratitude how Frank had insisted when the election results in December 1949 were clear, that ASB must not, as he was proposing, wait until the new prime minister called him, but should go to the Canberra Airport to welcome his new prime minister. Brown went. Menzies was appreciative. Allen Brown was off to a good start with his prime minister. 
The Coalition would have known that amongst the staff already transferred from Post-War was the active president of the ACT Branch of the Labor Party. It might have been this knowledge that prompted Menzies to ask Brown, somewhat diffidently, whether Brown was a member of the Labor Party. Brown replied, 'I wouldn't be seen dead in the Labor Party.' As Menzies expressed relief, Brown added, 'And I wouldn't be seen dead in the Liberal Party either.' This reply captured Menzies' fancy. It also accorded with the position Menzies felt a public servant should take. It fortified his acceptance of ASB and of the plans ASB had to develop the Prime Minister's Department.

Menzies accepted Bruno as a perfected public servant who had taken the oath of office and set store by its meaning. He could tell that ASB studied deeply, gave advice freely, and accepted responsibility cheerfully. As with any perfected public servant, these criteria existed within an envelope of vocation and mission; Bruno was the trusty custodian of the conventions and due process required by tradition, the Constitution and the rule of law. I remember an episode where, exceptionally, one of the Cabinet decisions recorded and issued by Brown was challenged. Brown had no doubt that the decision accurately reflected the Cabinet discussion and conclusion. However, the prime minister - as chairman of Cabinet - on being consulted had his own reasons for thinking otherwise. This did not present a problem for ASB. He simply signed off a decision that read: 'The Prime Minister has directed me to issue a decision in the following terms Quote ... Unquote'. Researchers looking over Cabinet decisions when the archives are released can find at least one other case where this format is invoked; there may be more.

ASB proceeded as quickly as he could to develop the Secretariat for Cabinet and its committees and to build up the department's advising capability. He had instituted the practice of Cabinet Notebooks from about the mid-1950s. Using his contact with Sir Norman Brook, ASB sent Ken Herde to the British Cabinet Office to get experience of the workings of their Secretariat. Cedric Cliffe came on short-term secondment from that Secretariat to Prime Minister's. I myself was sent for a somewhat longer posting to be under Robert Hall in the separate Economic Section of the British Cabinet Office. I saw Brown and Brook together in London at a foursome lunch hosted by ASB at Pruniers. They discussed the wine list. Brown selected a red - it may have been a Bordeaux 45. Brook thought the wine excellent but the price exorbitant. Brown quelled Brook's concern with 'Norman, we don't do this very often'.

I must mention one inspired intervention by McKenna, which Brown was pleased to support, and which paid huge dividends. This was the appointment of Jim Scholtens, later Sir James, KCVO, to fill a vacancy as Head of Ceremonial and Hospitality. McKenna said, 'Young Jim Scholtens could do that job.' ASB said, 'Frank, he's only an accountant, but if you think he can head CERHOS, we'll 
give him a trial.' It happened that Scholty had a remarkable likeness to Danny Kaye. Brown had occasion to chuckle some years later when on a visit to Japan the Japanese Major Domo made the famous introduction, 'The Prime Minister of Australia, Sir Robert Menzies, Dame Pattie Menzies and Mr Danny Kaye.'

The early 1950s were turbulent times politically with the Communist Party Dissolution Bill and its surrounds. Allen Brown negotiated this terrain with care. He had a keen sense of the proper role of a permanent public servant under a system of constitutional monarchy, democratic government and the rule of law. He had his counsels of perfection but also knew the real world. His first duty, consonant with his oath and pledge of office, was to provide honest, efficient, impartial administration and some assurance for the community of continuity in such administration. ASB recoiled from any politicisation of the public service. He stood ready to serve to the best of his ability, responsively and loyally, whatever political party might be in government. He would master the facts of an initiative or an issue and their analysis. He would ensure that his minister, in this case the prime minister, was fully informed on that basis - pointing out alternative courses of action and their consequences, not neglecting political consequences. He would present matters as they were with firm advocacy of courses of action but with this advocacy not pressed beyond the point where, aware of consequences, the minister takes a different view. Nevertheless, he was vigilant to identify where, by law or convention, matters fell within his responsibility and where they fell within the minister's. He would never usurp or intrude on the minister's responsibility or allow the minister or the minister's office to intrude on his.

By July 1955 Brown was sufficiently satisfied with the department's progress to marshal virtually its whole staff for a photo opportunity on the steps of Parliament House. I know of no other occasion when a secretary of a department arranged such a photograph. The assembly numbered 74, mostly young, and 26 of them women. The front row exquisitely reflects transition; it consists of ASB flanked by two old hands, Frank McKenna and Stan Temby, and on either side of them, the new generation, Jack (later Sir John) Bunting, whom Brown, in wise succession planning, was grooming to follow him, and Bob Durie who, but for his untimely death in the midst of a posting to Australia House, would have been returning to Australia to be Bunting's deputy.

In 1959, Brown decided on a career change. He became deputy high commissioner at Australia House. I had, and have, difficulty in understanding this move exceptional talent diverted to lesser purposes. He was only 48 years of age. Allen Stanley Brown was the most exemplary public servant I encountered in all my 42 years in the Commonwealth Public Service. 
This text is taken from The Seven Dwarfs and the Age of the Mandarins: Australian Government Administration in the Post-War Reconstruction Era, edited by Samuel Furphy, published 2015 by ANU Press, The Australian National University, Canberra, Australia. 